\title{
Violence Against Women In Punjab: Prevalence, Varying Trends And Efforts Of Media And Civil Society
}

\author{
Sadia Rafi \\ Mumtaz Ali \\ \& \\ Irfan Nawaz \\ Department of Social Work \\ University of Sargodha
}

\begin{abstract}
This study aims at highlighting common types of violence against women in Punjab, then present research discusses varying trends of violence against women in this province and efforts, which were taken by media, police, government of Punjab and civil society organizations, to combat violence against women were analyzed in broader context. Combating violence, it needs emergency measures to be taken and redefine continued efforts. Thus, it is suggested that it is the need of the hour to pave way for women friendly legislations and prohibits all practices of women violence by improving efficacy of existing policies for combating women violence.
\end{abstract}

$$
\begin{aligned}
& \text { ثلخيص }
\end{aligned}
$$

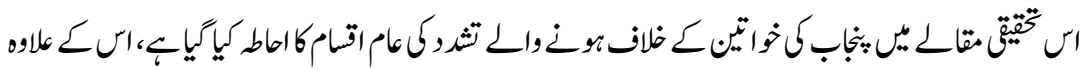

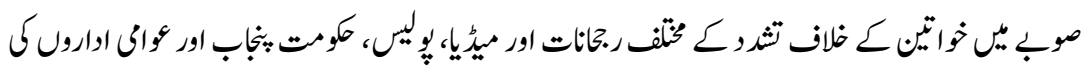

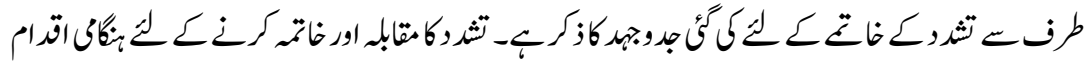

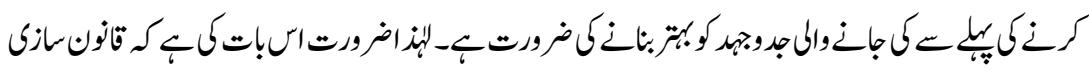

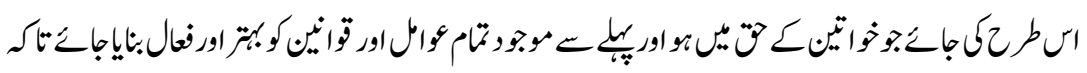

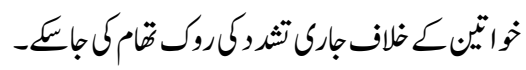

\section{Introduction}

In developed societies, man and woman are treated equally to great extent and enjoyed the same privileges and rights. They work like two wheels of vehicle of society for betterment. Unfortunately, some developing societies are not giving desirable importance to women because these societies are bound in some 
customary chains. These societies commonly have the patriarchal system where women take as inferior to man. In result, women are facing violence in daily matters widely.

United Nations General Assembly gave definition about violence against women "Any act of gender-based violence that results in, or is likely to result in, physical, sexual or mental harm or suffering to women, including threats of such acts, coercion or arbitrary deprivation of liberty, whether occurring in public or in private life (Symonides, 2002). However, violence against women is considered as major human rights problem in the world (Xavier, et al. 2009).

Violence against women has been recognized as a serious threat to women empowerment. This realization can be felt in this way that United Nations resolutions declared $25^{\text {th }}$ November as "International Day for the Elimination of Violence against Women" along with a convention, known as CEDAW, has been conducted which has been working since inception. Convention on the all forms of discrimination against women (CEDAW) elaborates all key steps for eliminating discrimination and bound each signatory state to follow it from heat and soul in their societies. Since $20^{\text {th }}$ century, women's rights have been frequently discussed. Ensuring equal rights for women, United Nations endorsed various international treaties and Declarations as Vienna Declaration, 1993 and $4^{\text {th }}$ women conference of Beijing, 1995. Unfortunately, all these efforts could not give equal rights to women.

Alarmingly, in South Asia, one of every two women experiences any form of violence in her daily life. In these worse conditions, there are certain factors which may be political, social, cultural and legal in nature contributing to make women vulnerable. Unfortunately, women violence is not taken as a serious threat or issue to human rights. Even though, women violence may leave impact on women's well-being, health, and fundamental rights (Niaz, 2003). In this region, violence against women is experienced at large, one among six female infant dies in Pakistan because of neglecting and discrimination. This violation may include rape, domestic violence, sexual violence, women trafficking, honour killing, disfigured with acid, custodial abuse and stove-burning.

Moreover, women are discriminated at all levels in society. Additionally, a sense of inferiority is being provoked among them by the society bended in traditional thoughts. Nevertheless, women are deprived from education and economic 
opportunities which restricts them to utilize their full potential. Keeping in mind, more than half of the population in Pakistan is consisted of female, so it is essential to raise their standard for making Pakistan prosperous (Rahman, 2009).

However, the fact is that situation of violence varies from area to area as it can be noticed that rural women is subject to discriminated more than a woman of urban area. In 2008, Human Rights Commission of Pakistan published a report which unveiled that $80 \%$ wives in rural Punjab have feared of violence by their husbands and in contrast about to $50 \%$ wives of urban areas have the same fear (Shaheed, 1990).

In this context, Muhammad Ali Jinnah, the founder of Pakistan, rightly said, "No nation can rise to the height of glory unless your women are side by side with you; we are victims of evil customs. There is no sanction anywhere for the deplorable condition in which our women have to live." (Jayawardena, 1996) But the ground realities are far worse, a girl, who was raped, went to Bet Mir Hazar Police station and she did self-immolation to get justice which seems inaccessible for her as suspect got bail last month. It is shameful that victims of rape in Pakistan need to take such measures to draw the attention to get their due justice. Similarly, a rape victim with her mother put themselves in cage; this act hopes that police may investigate this case more seriously. Unfortunately, the suspects had been bailed after intervention of a member of national assembly. These are some cases those are reported but the actual situation is worse than that, state cannot play its fair role and situation is getting worse in southern Punjab specifically (Dawn, 2014).

Summing up, violence against women is still deep-rooted in our society. Women are attacked and murdered because of using their rights to education, work and probably for taking key decisions in life. Moreover, there has been increase in heinous crimes like honour killings and acid attacks but miserable no effective measures are taken to prevent this raising trend (HRCP, 2012).

Therefore, this study explores the various forms of violence practising against women, then it gives comparative analysis of 2012 and 2013 regarding reported cases of violence against women and lastly it elaborates the efforts initiated by various agencies to combat violence against women. 


\section{Common Types of Violence Practicing against Women}

\section{Domestic Violence}

Domestic violence refers to threatening behaviours adopted by a person which may include emotional, physical, sexual and economic violence. It commonly aims to exert power upon other. Before inception of Pakistan, Muslims and Hindus lived together and share various traditions. Among those traditions, some are evolved from ignorant era which was made for suppressing women. Unfortunately, these traditions are still practicing in Pakistan which makes women second citizens of the society. Likewise, many wives were treated brutally of their minor mistakes in home affairs (Yoshihama, 1999).

\section{Sexual Assault}

Sexual assault means a person engages in sexual activity without explicit consent of the other person involved in. Sexual assault is probably high where women have subordinated status in the society. Nevertheless, customs of avenge, in which rape the enemies' women on order of arbitrator known as Sar-Punch of Punchiat. Such decisions are based on ignorant and inhuman customs and make women vulnerable.

\section{Sexual Harassment}

Sexual harassment refers to unwelcome sexual advances, sexual favour or any other physical, verbal or written intercourse. Additionally, sexual harassment at workplace means any act of sexual nature, whether physical, verbal or written, makes the work environment worse for the employers (G.O.P, 2010).

\section{Kidnapping}

Kidnapping refers to detain against your will by force. In Pakistan, women are kidnapped and used for trafficking across borders and also for prostitution. The true frequency of kidnapped women still remains a controversy because some women leave their home which aims to marry someone of her own choice. In response, victim family registers FIR (First incident report) as kidnapping case. Apart from it, the threatening rise has been seen in kidnapping of women in Pakistan. 


\section{Forced and Underage Marriages}

It is common belief in our society that timely marriages protect girls' morals and relieved parents of their responsibility to protect her, it is one of major reasons of early marriages in Pakistan. The term 'child' defined in Child Marriages Restraint Act 1929 as a male who is under 18 years and a female who is under 16 years. The child rights advocates are not satisfied with punishment of this crime. They believe that it is not productive in preventing this practice (HRCP, 2013).

\section{Traditional Modes of Violence}

In the $21^{\text {st }}$ century, still there are long-established modes of violence against women are using. These modes perceive women as an object and do not allow them to make a choice in marriage. Unfortunately, it is common in educated classes of society also. For protecting family's property, for instance, women are married to Holy Qura'n in Sindh. Likewise, tradition of Watta Satta ${ }^{1}$ in which the marriage of a brother and sister to another brother and sister for ensuing mutual exchange of property, and making pressure group in case of mistreating of either side. Probably, this system works against success of marriage. Likewise, young girls are often forced to marry someone as compensation for other's committed crime which is called Swara ${ }^{2}$ in Pushtun region and Vanni ${ }^{3}$ in Punjab (Babar, 2007).

\section{Honour Killings}

Honour killing refers to a person who assume that his wife, daughter, sister violated the norms concerned with traditional behaviour of women which ultimately damages man's honour and respect (Dawood, 1999).

\section{Murders}

Women are often murdered because of vested interests in less developed societies. Unfortunately, these issues are mostly keep in the dark because of restrict social patterns and weak system of justice. Resultantly, women become the most marginalized segment of society who has no right to have free life. 


\section{Suicide}

In this society, women are depressed and they cannot fight for their rights which may result in suicide most of the time, mostly deaths are of domestic disputes. Therefore, the rate of women's suicide is rising day by day.

\section{Violence in Custody}

It is often reported that Police is involved in women abuse in detention or imprisonment of women. These incidents closed the doors of justice to masses specifically for women because they cannot knock at the door of justice by this fear that Police is not for their protection.

\section{Efforts to Combat Violence against Women}

\section{Efforts of Media}

In the $21^{\text {st }}$ century, media has become most influential instrument of state. Therefore, media is called as fourth pillar of the state. But misuse of the power may make media as fifth column of the enemy. In addition, media sometimes exaggerated the issues and make it controversial which may causes for unrest in the society. In Pakistan, media has become a powerful sector to counter evils prevailing in the society but unfortunately women are still a marginalized segment of society. Therefore, media has national and moral duty to contribute in nation's development. Nevertheless, media can mould public opinion about specific problem and also works as pressure group. So, media should telecast talk shows in which they call experts who discuss burning issues. In their discussion, they focus on finding ways out of the existing problems. Likewise, dramas telecasted on television may base on such stories who give awareness about certain issues. In this way, media is struggling and trying to contribute in national development and prosperity. To some extent, media is succeeded but still a long way to go. Till now, media's role is satisfactory in developing consensus on social problems and specifically issues concerning violence against women. For instance, Dunya Television Network telecasted an episode titled as Stop violence against women. In this show, various eminent personalities were invited to shed light on this issue; Arifa Khalid Parvez, Pakistan Muslim League-N, Dr. Khalid Ranjha, famous lawyer, and Ibtisam Elahi Zaheer, renowned scholar, spoke on various 
perspectives of this issue. (Naji, 2014) In struggle of giving a worthy position to women, Sharmeen Obaid-Chinoy's role is admirable. She made a documentary named as "Saving Face" in which she highlighted the grave conditions of victim of acid throwing in Pakistan. Later on, this documentary won Oscar award and also force government to make some legislations in this way (Tribune, 2012).

Newspapers publish time to time different reports and news to highlight the gravity of situation regarding violence against women as Dawn, a well-known English newspaper, published a report entitled as violence against women on the rise in which it unveiled the raising trend vis-à-vis violence against women. So It is vital to play due role by all stakeholders in combating social evils of society (Dawn, 2014). In this way, Nomad art gallery organized an event in collaboration with UN women aimed at highlighting violence against women and it also brings attention towards the inaccessibility of justice to women (Tribune, 2012).

Furthermore, efforts are being made by all franchises of media at different scale. As ARY news, a media franchise in Pakistan, Published an article named as eliminate violence against women, it aimed at creating awareness about $25^{\text {th }}$ November which is celebrated as international day for Elimination of violence against women. This article tells about the baseline of celebrating this day, gives information about alarming trends of acid throwing cases and demand for emergency measures to be taken.

Thus, media is an instrument to bring positive change in the society in brief time. So it is necessary to work it independently in bringing up core issues of society so that it can mould public opinion in positive ways which may ultimately leads to eliminate social evils like violence against women.

\section{Efforts of Police}

Police is a civil force responsible for maintaining internal peace, harmony and stability in the society. It does all this irrespective of gender, caste, creed, ethnicity and religion. Likewise, in Pakistan, Police was established on the same lines. Unfortunately, Police could not make its image on above lines and it's image is getting worse day by day. At last, Pakistan is considered among those states where general public shows least interest on Police department. Behind this worse conditions, certain factors can be sort out which are mainly corruption, inefficiency and outdated structure of Police department. The sad incident of 
torture and rape of a woman by three policemen filed in Lahore High court last year raised severe concerns on performance of police department in protecting and strengthening women folk (Haidar, 2013). More specifically, police also could not play its due role in women concerned issues. Unfortunately, it has been commonly observed that majority of victim women cannot access to even file First Information Report (FIR). Moreover, there are less numbers of Women Police stations and if these are then majority of women are unaware of it. Fortunately, if any women get access to police station, she is misbehaved because of male dominance in society. The worsening fact is that sometimes those women were raped in police custody because of some evil political causes. But it does not mean that police is not making efforts in protecting women folk. Moreover, police successfully thwarted marriage of 11 year old girl with a young boy of 12 years (HRCP, 2013).

\section{Efforts of Government of Pakistan}

Government is the largest agency in society to work for betterment of all segments of society. Therefore, it has more responsibility to protect women folk. No doubt, government is struggling to give women folk a respectable place in this patriarchal society. Yet many more needs to do in this way; the negligence has been noticed in establishing women's shelter homes and there is no proper mechanism for investigations and scarcity of trained personnel. On the other hand, Punjab government are taking initiatives to empower women so that intensity of women violence can be minimized. On $8^{\text {th }}$ march, celebrated as Women's day, it announced Women's empowerment Package. This package provides policy proposals to protect women's rights and improve their social and economical conditions in society (HRCP, 2012).

Actually, government realized that a woman violence can be minimized and ultimately will keep it to the end is only can be possible by ameliorating women's socio-economical conditions of society. Therefore, apart from women's empowerment package, Government of Punjab declared 2 billion Pakistan rupee fund to Bank of Punjab, a government-owned bank, to provide microfinance to women folk. Besides, government increased the women quota in government jobs from $5 \mathrm{pc}$ to $15 \mathrm{pc}$. Also, Government of Punjab created 30 new positions in the department of women's development. The most admirable initiative was allocation of Rs. 14 billion to women's cause in budget 2012-13. Along with above steps legislations are also crucial in minimizing women grievances and 
strengthening women folk. In this regard, federal government is more instrumental rather provincial government. Therefore, a bill of Acid Throwing and Burn Crime Bill 2012 was submitted in National assembly which covers reporting, investigations, collecting medical proves and protection of witnesses and victim (HRCP, 2013).

\section{Efforts of Civil Society}

In welfare societies, civil society organizations have pivotal role. These organizations work as an advocate for marginalized segments of society and also act as pressure group to influence others. But situation is not the same in every societies, it varies from region to region. In Pakistan, civil society organizations are facing hard times, they cannot work independently. Even though, they are striving for protecting the suppressed segments of society. In matter of Violence against women, these organizations time to time contribute in raising concerns vis-a-vis women grievances. Aurat foundation, a famous NGO working for women rights, conducted a session with relevance of international women's Day 2014. This session was conducted with domestic female workers under its program of Gender Equity Program (GEP). This session gave information about helpline for psycho-social counselling, referrals and opportunities for its GEP program. Additionally, domestic female workers discussed their problems and most discussed problem is sexual harassment of female workers. These efforts bring into light the issues of violence against women, also help in convincing people to stand firmly against violence concerning women and laid emphasis to mould social attitudes towards women in this society (Aurat, 2014). Then, with collaboration in Mukthar Mai Women's Organization, Aurat foundation protested in front of Multan Press club against occurrence of frequent incidents of gangrapes, violence and discrimination of women in Punjab. Aurat foundation strongly condemned these incidents and demanded for approval of Domestic Violence Bill as soon as possible. Participants slammed incidents of burning a lady to her in front of police station and demanded for strict action against such criminals. (Aurat, 2014). Similarly, White Ribbon campaign in Pakistan is remarkable stable as it aims at taking pledge never to commit, excuse and remain silent about violence against women (White Ribbon Campaign, 2013).

These efforts are a little contribution by civil society organizations but helps in strengthening women in such societies who are stick to their primitive values. If 
civil society organizations are given room to work independently, they can bring positive results in short period of time.

\section{Conclusions}

Women in Pakistan are facing various problems. Among those, violence against women is dominant and increasing rapidly as often cases were reported. Unfortunately, no admirable efforts, so far, have been made which, in conseqence, affects a large proportion of Pakistani population. Minimizing women violence may lead to socio-economic prosperity of women that ultimately can boost nations dwindling economy and also bring harmony among daily life tasks performed by both genders.

\section{Recommendations}

1. Remove impediments in the way of women friendly legislations because legislations empower women to take step against evil traditions of the rigid societies. Moreover, majority of women do not take steps against such violence because they are not empowered by the law through legislations.

2. Government should make possible implementation of CEDAW in its true sense. Its implementation helps in strengthening women in Pakistan which have been suppressing since long and become vulnerable segment of society.

3. Necessary steps should be taken by government with collaboration of civil society organization to empower women's socio economic conditions because socio-economic dependency is amongst core reasons of women violence.

4. There is acute shortage of women police stations across the province, this shortage impedes women to access to police station with ease. In this way, women cannot file their complaints about violence.

5. Early marriages cause to increase violence against women because immature girl cannot take the burden of household, in failure of managing husband often get violent. For curbing this, minimum age of marriage should be 18 years. If someone tries to violate this law, police should have full authority to act against it. 


\section{End Notes}

1. Watta satta literally means give and take; it refers to bride exchange commonly practiced in Pakistan. In addition, it also involves marriage of brother and sister pair form two households simultaneously (Wikipedia, Watta satta).

2. Swara is largely practiced in pushtoon communities. This act refers to give girl or girls in marriage to the victim family instead of blood money which aims at settlement of blood feud between two households (Usafzai, 2004).

3. Vani is found in some parts of Pakistan in which girls are forcibly married as compensation of the crime committed by their male relatives (Wikipedia, Vanni).

\section{References}

A. F. (2014). Protest held against prevailing incidents of violence in South Punjab, Lahore. Retrieved 05 04, 2014, from Aurat Foundation: http://www.af.org.pk/activity-detail.php?nid=77

Babar, Z. U. (2007). Violence Against Women in Pakistan : Current realities and strategies for change. Retrieved 05 04, 2014, from European Peace University: http://epu.ac.at/fileadmin/downloads/research/Babur.pdf

Dawn. (2013, 12 05). Dawn.com. Retrieved 5 21, 2014, from Dawn: http://www.dawn.com/news/1060643/violence-against-women

Dawn. (2014, 02 14). Violence against women on the rise. Retrieved 06 01, 2014, from Dawn.com: http://www.dawn.com/news/695507/violence-againstwomen-on-the-rise-2

Dawn. (2014, 03 14). Rape victim who set herself Ablaze dies. Retrieved 2203 , 2014, from Dawn.com: http://www.dawn.com/news/1093090

Dawood, A. (1999). Karo-kari: A question of honour, but whose honour. Retrieved 05, 04, 2014, from reocities: http://reocities.com/attiyadawood/arti03.html 
Foundation, A. (2012). Beyond Denial. Islamabad: Aurat Publication and Information Service Foundation.

G.O.P. (2010, March). THE PROTECTION AGAINST HARASSMENT OF WOMEN AT THE WORKPLACE ACT 2010. Retrieved May 04, 2014, from www.qau.edu.pk/pdfs/ha.pdf

Haidar, R. (2013, 04, 28). Policemen accused of raping woman escape from police custody. Retrieved 05 02, 2014, from Pakistan Today: http://www.pakistantoday.com.pk/2013/04/28/city/lahore/policemenaccused-of-raping-woman-escape-from-police-custody

HRCP. (2012). State of Human Rights in 2012. Lahore: Human Rights Commission of Pakistan.

HRCP. (2013). State of Human Rights in 2013. Lahore: Human Rights Commssion of Pakistan.

Jayawardena, K. A. (1996). Embodied Violence: Communalising Women's Sexuality in South Asia. New Delhi: Kali for Women.

Naji, A. (2014, 02, 01). Talaash. (A. K. Parvez, K. Ranjha, \& I. E. Zaheer, Interviewers)

Niaz, U. (2003). Violence against women in South Asian countries. Archives of Women's mental health , 173-184.

Rahman, F. (2009, 09 04). Violence against women turning from bad to worse. The Nation, http://nation.com.pk/islamabad/04-Sep-2009/Violenceagainst-women-turning-from-bad-to-worse

Shaheed, F. (1990). Pakistan's women: an analytical description. Lahore: Shirkat Gah.

Symonides, J. \&. (2002). A guide to human rights- institutions, standards, procedure-women and human rights. France: UNESCO Publications. 
Tribune. (2012, 02, 27). Sharmeen Obaid-Chinoy's documentary wins Oscar. Retrieved 05 01, 2014, from Tribune: http://www.tribune.com.pk

Tribune. (2012, 12 01). Violence against women highlighted in mixed Media show. Retrieved 05 30, 2014, from Tribune.com.pk: http://tribune.com.pk/story/473809/violence-against-women-highlightedin-mixed-media-show/

Usafzai, Z. A. (2004, 02 20). the Price of Honour. The Statesman, http://www.khyber.org/culture/a/Swara_The_Price_of_Honour.shtml

White Ribbon Campaign Pakistan. (2013). Retrieved 03 05, 2014, from http://www.whiteribbon.org.pk/media-award-2013/

Wikipedia. (n.d.). Vanni. Retrieved 05 11, 2014, from Wikipedia: http://en.wikipedia.org/wiki/Vani_\%28custom\%29

Wikipedia. (n.d.). Watta satta. Retrieved 05 23, 2014, from Wikipedia: en.wikipedia.org/wiki/Watta_satta

Xavier, S.-i.-M., Blanke, J., Drzeniek, M., Geiger, T., \& Mia, I. (2009). The Global Competitivness Report 2009-2010. Geneva: World Economic Forum.

Yoshihama, M. (1999). Domestic Violence: Japan's hidden crime. Domestic violence Action and Research Group in Japan. Japan Quart 46(3) JulySeptember.

Dr. Sadia Rafi is Assistant Professor in the Department of Social Work, University of Sargodha.

Dr. Mumtaz Ali is Assistant Professor in the Department of Social Work, University of Sargodha.

Irfan Nawaz is M.Phil Scholar in the Department of Social Work, University of Sargodha. 